\title{
Niche differences between sympatric Sargassum species in the northern Gulf of California
}

\author{
Richard M. McCourt
}

Department of Ecology and Evolutionary Biology, The University of Arizona, Tucson, Arizona 85721, USA

\begin{abstract}
Sargassum johnstonii Setchell \& Gardner, S. herporhizum Setchell \& Gardner, and $S$. sinicola Setchell \& Gardner var. camouii (Dawson) Norris \& Yensen display spatial separation in largeand small-scale zonation patterns and habitat differences at low tide on an intertidal coquina limestone reef in the northern Gulf of California, Mexico. On a small scale within mid-intertidal pools, $S$. johnstonii occurs in the shallowest depths, followed by $S$. herporhizum and S. sinicola var. camouii at successively greater depths in the pools. On a large scale in the lower intertidal zone on emergent coquina $S$. johnstonii again occurs in the uppermost position in zonation, with $S$. herporhizum below. In this lower area the distribution of $S$. sinicola var. camouii overlaps with that of emergent $S$. herporhizum but most plants of the former species occur in pools. Thus, in the same low-tide habitat (pools or emergent coquina) the species occupy the different vertical zones, whereas when they do occupy the same vertical zone they occupy different habitats. At some sites where $S$. herporhizum and tide pools are rare or absent, $S$. sinicola var. camouii in the intertidal zone shifts its habitat from tide pools to mostly emergent habitats.
\end{abstract}

\section{INTRODUCTION}

Species of Sargassum frequently constitute the most abundant overstory algae on tropical and subtropical shorelines (Fritsch, 1945; Stephenson and Stephenson, 1972; De Wreede, 1976; Prince and O'Neal, 1979). Studies of intertidal zonation of Sargassum have demonstrated that the genus is generally found in low intertidal areas and tide pools (Stephenson and Stephenson, 1972; De Wreede, 1973, 1978). Few studies have documented zonation and habitat differences of several Sargassum species occurring in the same intertidal area (Tsuda, 1972; De Wreede, 1973). Differences between species are most apparent against a background of similarity, and for congeneric species, differences in the spatial dimensions of their niches indicate some of the underlying mechanisms determining distributions. These differences are more significant when, as in the present situation, the species involved are the predominant, large components of the vegetation canopy.

This paper documents differences in intertidal zonation and habitat between Sargassum johnstonii Setchell \& Gardner, S. herporhizum Setchell \& Gardner, and S. sinicola Setchell \& Gardner var. camouii (Dawson)
Norris \& Yensen near Puerto Peñasco, Sonora, Mexico. These large-scale patterns will be compared to zonation and habitat features occurring on a small scale within tide pools.

Species of Sargassum are the only algae in the Gulf of California that approach the size of kelps (Laminariales), which are virtually absent from the region (Dawson, 1944; Norris, 1975). Sargassum plants form a large habitat for a diverse assemblage of invertebrates (Brusca, 1980), fishes (Thomson and Lehner, 1976), and epiphytic and understory algae (Dawson, 1966). Niche differences between Sargassum species will affect and be affected by these assemblages.

Intertidal zonation of algae in the northern Gulf of California has been the subject of few reports. Littler and Littler (1981) studied intertidal zonation of algae at Pelican Point, near one of the study sites of the investigations reported here. They, however, were primarily interested in aspects of productivity and morphology of smaller, higher intertidal species rather than the delineation of zonation and habitat differences. Moreover, their study did not include the extensive stands of Sargassum in the low intertidal zone at Pelican Point. Recent studies of seasonal patterns of 
abundance of algae in this region include those of Wynne and Norris (1979), Norris and Yensen (in press), and McCourt (1983,1984).

Mackie and Boyer (1977) described the zonation of macroinvertebrates at Station Beach in the northern Gulf of California, one of the sites investigated in my study. They found that zones were more diffuse than those typical of many shorelines (Lewis, 1964; Ricketts et al., 1968; Stephenson and Stephenson, 1972). Mackie and Boyer (1977) postulated that the less distinct zonation at Station Beach is due to the greater variety of habitats afforded by the soft coquina limestone reef and the gentle slope of the reef that results in a correspondingly gentler exposure gradient. Brusca (1980) presented a generalized zonation scheme for intertidal communities throughout the Gulf of California and concluded that invertebrate intertidal communities display very few of the discrete zones typical of California coastlines. The present study examined the discreteness of intertidal zonation of a closely related set of algae that are important vegetational components of such communities.

\section{MATERIAL AND METHODS}

\section{Study sites}

The 3 study sites were in the vicinity of Puerto Peñasco, Sonora, Mexico, in the northern Gulf of California (Fig. 1). The physical environment has been described in detail by Thomson and Lehner (1976). Monthly onshore sea surface temperatures average near $14^{\circ} \mathrm{C}$ in winter and $30^{\circ} \mathrm{C}$ in summer. Exposed tide pools in intertidal areas are subject to slightly greater extremes in temperature in both winter and summer (Thomson and Lehner, 1976). Spring tide range at Puerto Peñasco exceeds $7 \mathrm{~m}$ (Thomson, 1981) and is among the largest in Pacific North America. Hereafter, tide levels will be expressed in meters in relation to mean low water, which serves as zero-tide level on the annual tide calendars for the northern Gulf of California (Thomson, 1981).

Two of the 3 study sites, Station Beach and Las Conchas (Fig. 1), were located on an unbroken stretch of south-facing coastline that extends from Puerto Peñasco to the mouth of a negative estuary, or estero, Estero Morua. Low tides expose a reef made of coquina limestone, an erodible substrate easily penetrated by the holdfasts of many algae. Extensive erosion has produced tide pools and depressions ranging from centimeters to tens of meters in diameter. The intertidal coquina reef is divided into 2 major topographic areas by a fault in the reef at about the zero-tide level, below which the reef slope becomes steeper.

Throughout its length the reef is bordered above by a shell-fragment beach and below by a sandy-bottom subtidal area. Sand and shell fragments collect in the bottoms of the pools and in patches on the reef. Sand is progressively more abundant eastward on the shoreline until the reef is nearly covered by sand at the mouth of Estero Morua. In addition, the slope of the reef becomes more shallow toward the estero.

The third site surveyed was Pelican Point, $10 \mathrm{~km}$ northwest of Puerto Peñasco (Fig. 1). The section of shoreline studied faces southwest and has a steeper slope than those of the other sites. The substrate is mostly granitic outcrops and boulders, with an expanse

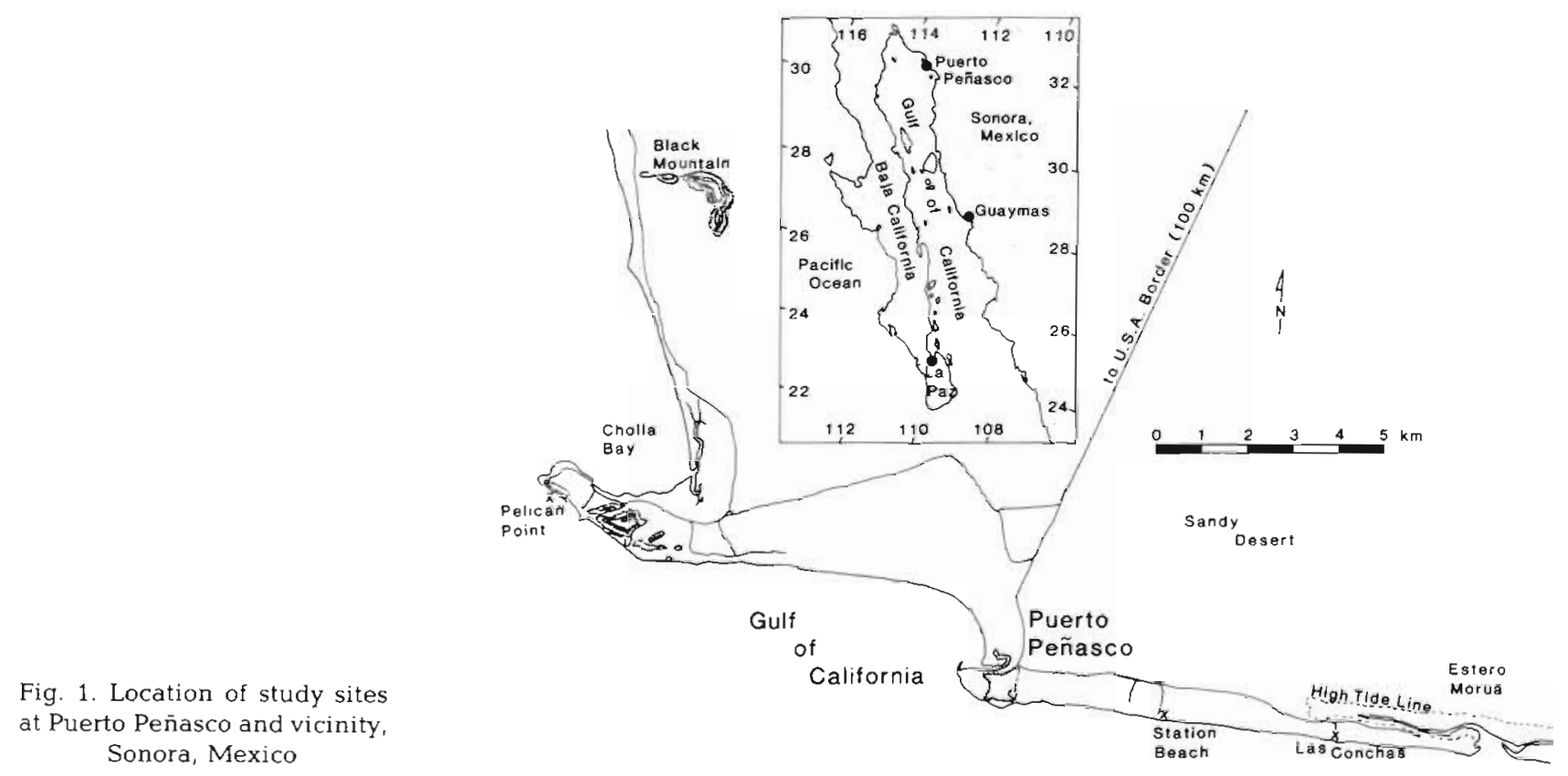


of coquina only in the lowest region of the intertidal zone. Despite its proximity to the Cholla Bay mud flats and a sandy-bottom subtidal area, sand accumulation appears comparable to that at Station Beach.

\section{Species studied}

Three Sargassum species occur in the northern Gulf of California (Norris and Yensen, in press): S, johnstonii, S. herporhizum, and $S$. sinicola. Two varieties of S. sinicola occur at Puerto Peñasco: var. sinicola and var. camouii. The investigations reported here centered on S. johnstonii, S. herporhizum, and S. sinicola var. camouii. S. sinicola var. sinicola occurs on subtidal patch reefs and rarely in the intertidal zone. Throughout this paper, $S$. sinicola refers only to the variety camouii unless otherwise noted. Further discussions of the taxonomy and morphology of the species have been provided by Norris and Yensen (in press) and McCourt (1983)

\section{Intertidal transects}

Norris and Yensen (in press) and McCourt (1984) have described seasonal patterns of abundance of the 3 Sargassum species in the study area. All species are most abundant in late winter and in spring. McCourt (1984) reported that, despite seasonal differences in abundance, the species maintained differences in habitat and relative position in the zonation pattern throughout the year.

The basic pattern of intertidal zonation on Station Beach was documented in fall 1977 in the area near a large tide pool $(70 \times 20 \mathrm{~m})$ known as Station Pool. Five transects, spaced $10 \mathrm{~m}$ apart, were established, extending perpendicular to the shoreline from the upper limit of the coquina reef $(+1.8 \mathrm{~m})$ to the lowest spring-tide level $(-1.8 \mathrm{~m})$. Transect length ranged from 90 to $110 \mathrm{~m}_{\mathrm{i}}$ some transects were shorter than others due to submergence of the lowest segments during census and to differences in reef slope between transects. At $10-\mathrm{cm}$ intervals along the transect line, presence of a species of Sargassum was recorded if a portion of the plant lay beneath that point on the line. Plants were traced to their holdfasts, which were noted as either in tide pools or on emergent reef. "The terms 'emergent' and 'tide pool' refer to a plant's habitat at low tide. Percent occurrence for each species in 5-m intervals was calculated as the number of points at which a species occurred divided by the total number of points sampled and multiplied by 100 . This was taken to be an estimate of the percentage of the substratum covered by the canopy of Sargassum plants.
Intertidal distributions at the other study sites were surveyed in late winter and spring. One site, Las Conchas, provided an example of Sargassum zonation in a very sandy area. Two transects were surveyed at this site in February 1981. The other site, Pelican Point, provided 2 different types of solid substrate, coquina and granite, with the former restricted to the lowest part of the intertidal zone. Five transects were surveyed at Pelican Point in April 1981. Data collected in spring 1981 from 5 Station Beach transects are also presented for comparison with that from transects at these other sites.

Topographic profiles were mapped for transect stations, using the Emory line method (Dawes, 1981). Elevations relative to the zero-tide level and substrate type were recorded at 5-m intervals.

\section{Pool transects and habitat measurements}

Transects were conducted across 14 tide pools of various sizes and depths in the lower mid-intertidal $(+0.6 \mathrm{~m})$ interval at Station Beach in spring 1977 to determine the distribution, habitats, and sizes of Sargassum on a small scale within tide pools. Transects were established across the centers of Sargassum patches in the pools. Data recorded at $10-\mathrm{cm}$ intervals along the line were: species of Sargassum, if present; maximum length of plant; and water and sand depths at the plant's holdfast. Linear measurements were made to the nearest $0.5 \mathrm{~cm}$. Combined length of all transects totaled $42.5 \mathrm{~m}$, and 293 Sargassum plants were sampled.

\section{RESULTS}

The distribution of Sargassum will be described on 3 spatial scales. First, zonation of the three species in the intertidal zone at Station Beach will be described. The basic zonation scheme will then be compared to zonation patterns at the other sites. Finally, differences between species on a smaller spatial scale will be documented with data on zonation, habitats, and plant size within tide pools.

\section{Intertidal transects}

Canopy cover on the Station Beach transects in autumn 1977, estimated from total percent occurrence for all 3 Sargassum species, was $28 \%$ of the reef area. The canopy cover of S. sinicola was $17 \%$, about 3 times that of $S$. herporhizum (6\%) and $S$. johnstonii ( $5 \%$ ). Most of the remaining $72 \%$ of the reef area was covered by emergent algal turf such as that described 
for this area by Stewart (1982), sand in tide pools, and various sessile animals.

Two distinct zones of Sargassum distribution were identified: an upper zone above $+0.3 \mathrm{~m}$ and a lower zone below $-0.3 \mathrm{~m}$ (Fig. 2). These zones were separated by the reef fault at the zero-tide level, $60 \mathrm{~m}$ from the top of the transects (Fig. 2). The abundance of $S$.

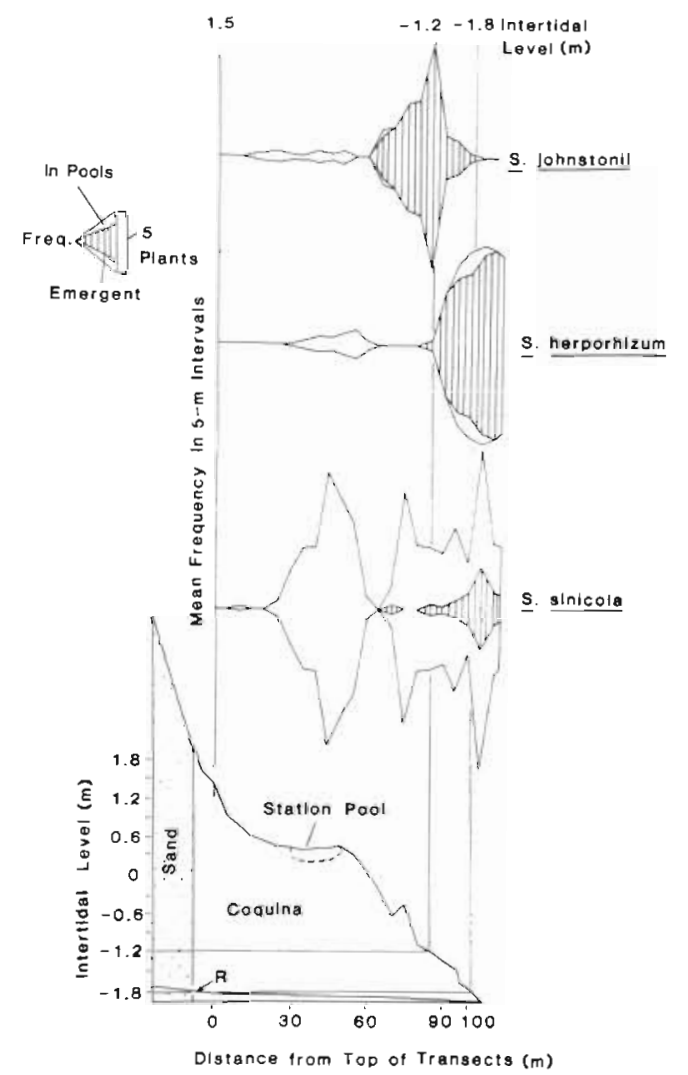

Fig. 2. Intertidal distribution of Sargassum species at Station Beach, fall 1977. $R=$ profile with both axes at same scale

sinicola was similar in both upper and lower zones. $S$. johnstonii and $S$. herporhizum were markedly more abundant in the lower than in the upper zone.

The Sargassum species showed distinct differences in their occurrence in emergent or pool habitats on these transects. Most (93\%) S. sinicola occurred in pools throughout both zones (Fig. 2). In contrast, the habitats of $S$. herporhizum and $S$. johnstonii were mostly emergent ( 77 and $91 \%$, respectively), particularly in the lower zone.

Above the reef fault all Sargassum species were restricted to the pools. The hiatus in Sargassum occurrence between approximately $+0.3 \mathrm{~m}$ and $-0.3 \mathrm{~m}$ coincided with the absence of pools across the reef fault. Pools were common below $-0.3 \mathrm{~m}$, although usually only $S$. sinicola occurred in pools in the lower zone.
In the lower zone outside the pools, Sargassum johnstonii and $S$. herporhizum occurred primarily on emergent coquina and were vertically zoned (Fig. 2). S. johnstonii was almost entirely absent below $-1.5 \mathrm{~m}$. Below this point $S$. herporhizum was the most abundant Sargassum on emergent coquina, growing in large monospecific stands. A few patches of $S$. sinicola were found on emergent coquina at this very low tide level, but most plants of this species were found in pools.

In Fig. 2 the distributions of Sargassum sinicola and $S$. herporhizum appear truncated only because the transects were terminated at the water's edge. Both species occur subtidally, but $S$. sinicola extends farther seaward than $S$. herporhizum on coquina patch reefs on the sandy bottom. Sargassum zonation patterns at Station Beach (Fig. 3) in 1981 were similar to the pattern found at Station Beach in 1977 (Fig. 2) despite

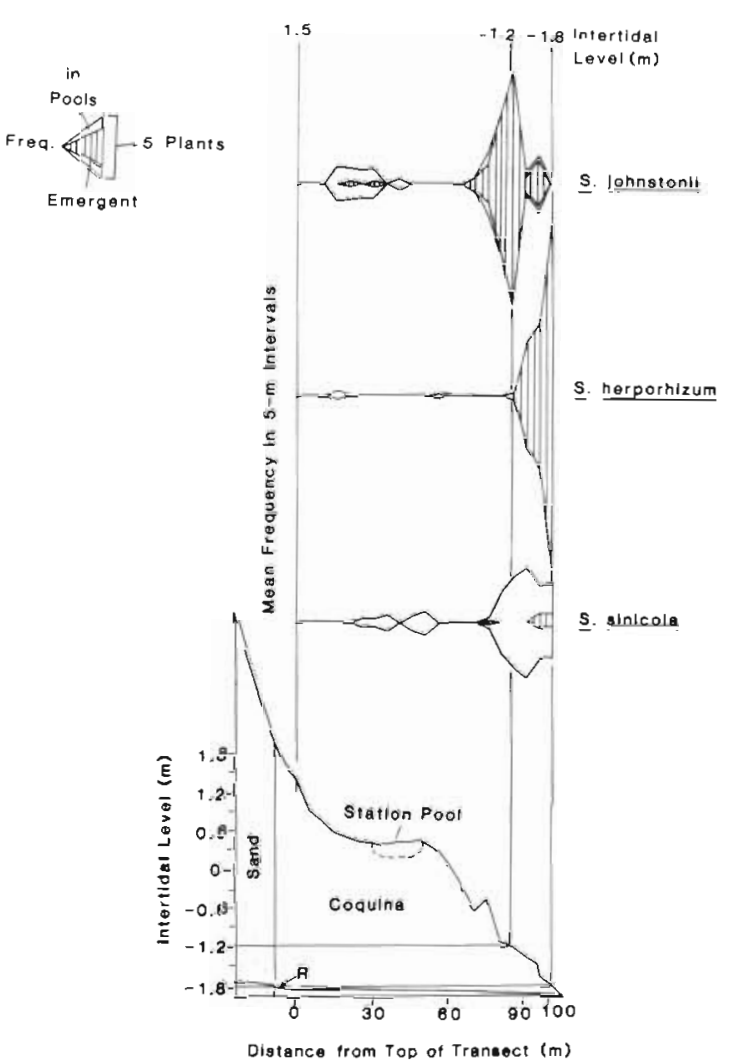

Fig. 3. Intertidal distribution of Sargassum species at Station Beach, spring 1981. $R=$ profile with both axes at same scale

changes in abundance (McCourt, 1984). S. herporhizum dropped out of the zonation pattern between Station Beach and Las Conchas; there were almost no S. herporhizum on the reef at Las Conchas (Fig. 4). On the transects themselves only one small patch of $S$. herporhizum occurred in a pool. A search of the reef for $50 \mathrm{~m}$ in either direction failed to turn up more plants of 
this species. Nor were any found in a search of the reef up to $2 \mathrm{~km}$ westward of the transects. The Las Conchas shoreline has a much more gradual slope than the other sites (Fig. 4). Despite a larger intertidal zone there is less coquina substrate here because much of the intertidal zone is covered by sand

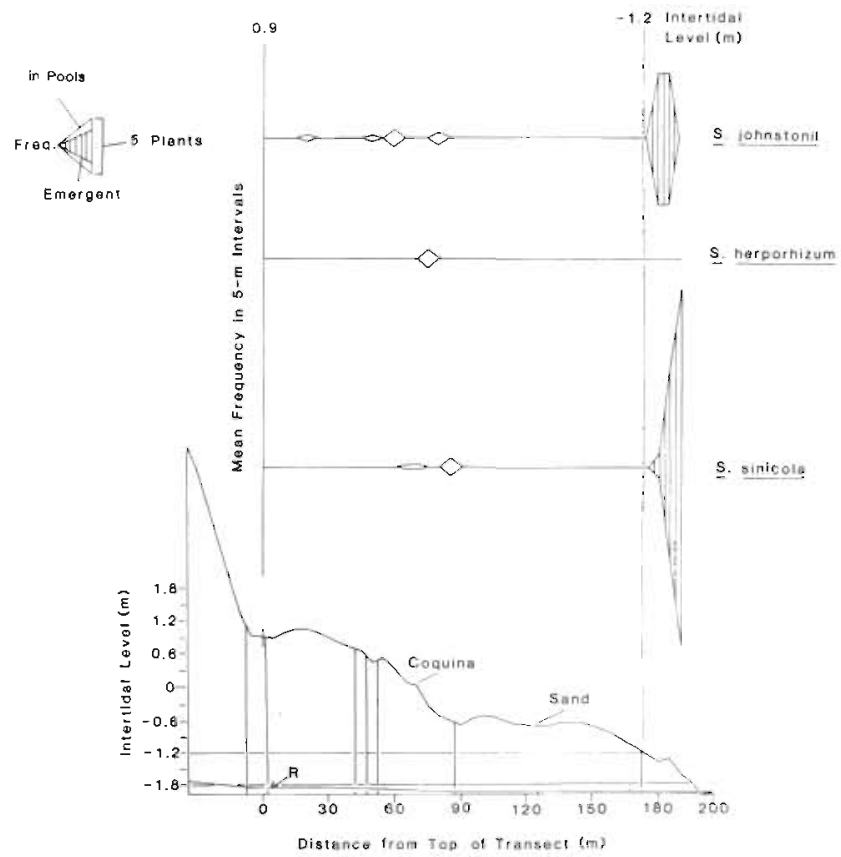

Fig. 4. Intertidal distribution of Sargassum species at Las Conchas, spring $1981 R=$ profile with both axes at same scale

In contrast to its abundance in the lower zone at Station Beach, Sargassum herporhizum was relatively scarce at Pelican Point, where Sargassum plants were largely restricted to the lower intertidal zone on the emergent parts of the coquina shelf (Fig. 5). Pools were infrequent on the shelf and no large tide pools comparable to Station Pool occurred at Pelican Point. $S$. herporhizum was occasionally found in tide pools in the granitic outcrops higher in the intertidal zone, although no pools occurred on the transects.

At sites where Sargassum herporhizum was scarce (Pelican Point) or absent (Las Conchas), a larger proportion of plants of $S$. sinicola occurred in emergent habitats. The relative frequencies of $S$. sinicola plants occurring in emergent or pool habitats at these sites were the reverse of those at Station Beach: most plants occurred on emergent coquina instead of in pools (Fig. 6). S. johnstonii and $S$. herporhizum occurred primarily on emergent substrate at all sites (Fig. 6) (the $3 S$. herporhizum plants at Las Conchas were in 1 tide pool).

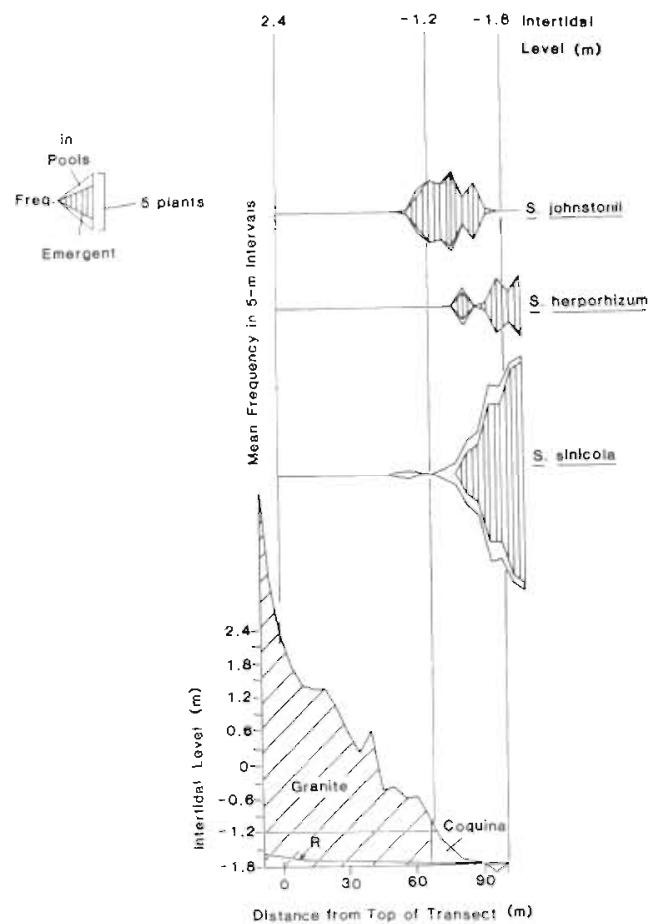

Fig. 5. Intertidal distribution of Sargassum species at Pelican Point, spring 1981. $R=$ profile with both axes at same scale

\section{Pool transects and habitat measurements}

Data from the 14 pools sampled at Station Beach were combined for presentation. When data from individual pools were analyzed separately, the same trends were evident, but sample sizes were sometimes too small to achieve statistical significance. Withinpool deviations from trends in the combined data are noted.

Mean water depths for the 3 species (Fig. 7) were significantly different $(p<.01$, Welch's ANOVA as described by Dixon and Brown, 1979; and pairwise $t$ test). This depth zonation in pools was similar to the zonation pattern on emergent coquina at Station Beach (Fig. 2). Sargassum johnstonii occurred in shallow water near the edges of pools, whereas $S$. herporhizum and $S$. sinicola occurred in successively deeper parts of the pools.

Average depth for Sargassum sinicola in a pool correlated with maximum depth in the 14 pools ( $r=.800$, $p<.01$ ), i.e. this species always tended to occur in the deeper parts of pools regardless of the pool depth. Average depth of $S$. herporhizum correlated less closely $(r=.367, p>.05)$ with maximum depth in the pool because even in the deepest pools, plants still occurred at only intermediate depths. Average depth of $S$. johnstonii plants at the edges of pools was independent of maximum pool depth $(r=.005, p>.05)$. 


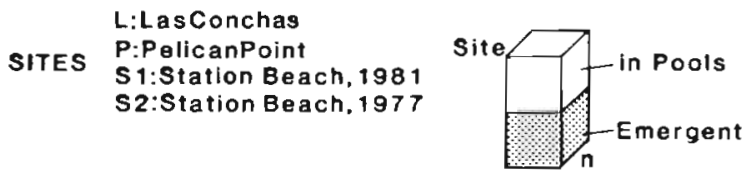

\section{S. johnstonii}

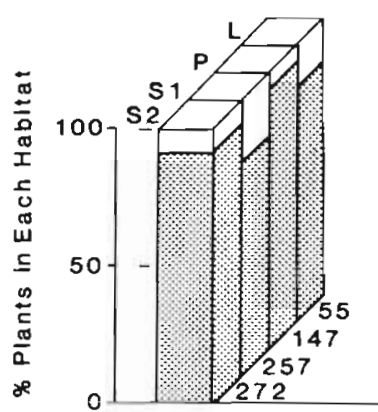

\section{S. sinicola}

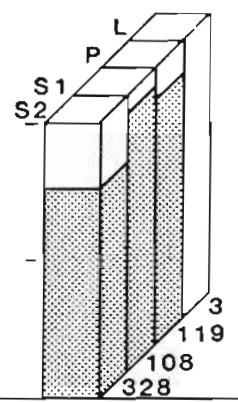

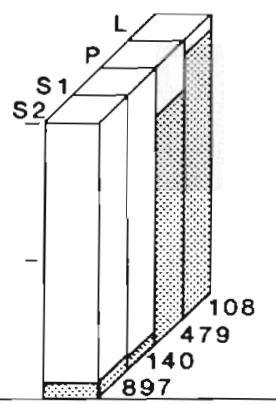

Fig. 6. Percentage of plants of each Sargassum species in pool or emergent habitats on transects at 3 sites in the vicinity of Puerto Peñasco
Thus, regardless of the maximum depth of the pool, the 3 species maintained the same positions relative to their average water depths.

The lengths of Sargassum herporhizum and $S$. sinicola plants correlated positively with the water depths at which they were found, $(r=.597, n=130$, $p<.01$ and $r=.422, n=128, p<.01$, respectively). The length of $S$, johnstonii did not correlate with water

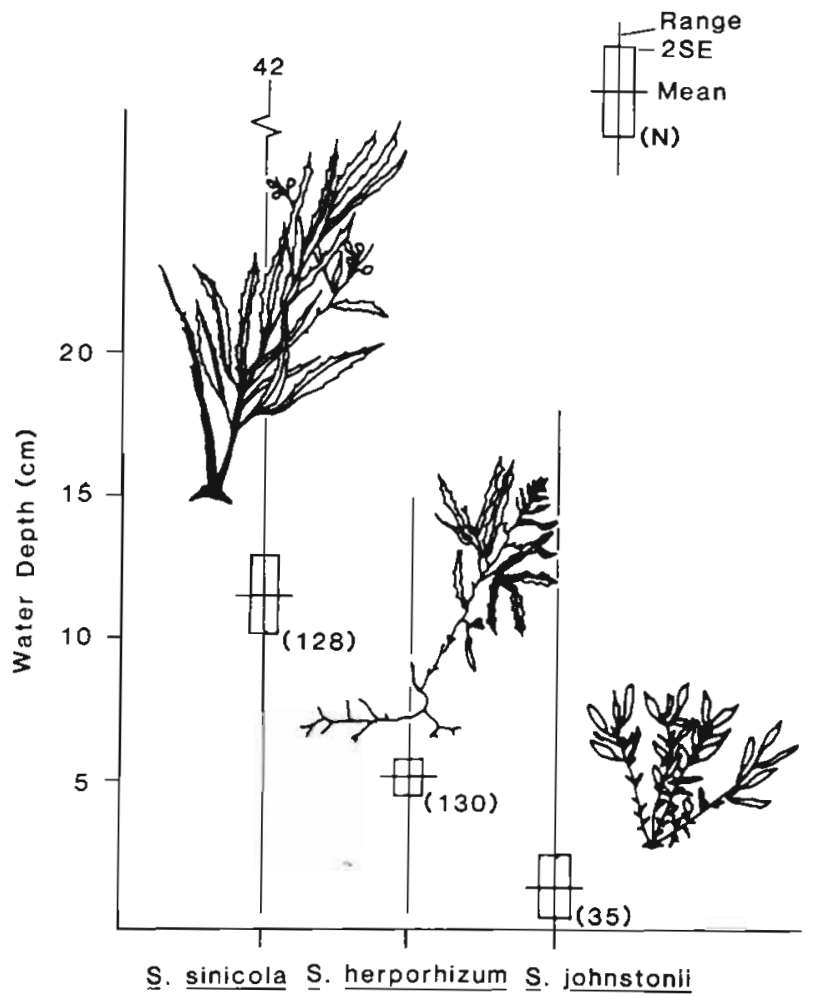

Fig. 7. Mean water depths of the Sargassum species in Station Beach tide pools depth of the plant $(r=-.072, n=35, p>.05)$. The 3 species also showed significant differences in average length (Fig. 8) ( $p<.01$, Welch's ANOVA, and pairwise t' tests). Sargassum johnstonii, whose Iength was independent of water depth, attained the greatest length (Fig. 8).

Average sand depths for the 3 species (Fig. 9) showed a pattern similar to that for average water depths, which would be expected because sand accumulates in the deeper parts of pools. Sargassum johnstonii had the shallowest mean sand depth, significantly different from depths for the other species $\left(p<.03\right.$, Welch's ANOVA, and pairwise $t^{\prime}$ tests). Mean sand depth for $S$. herporhizum was less than that for $S$. sinicola, but the difference was not statistically significant. Sand levels are dynamic and a plant must deal with a wider range of sand depths than water depths. Although water in a tide pool may partially drain out during low tide, sand cover can change rapidly between tides when wave action either deposits or removes sand. Variation of sand depth in the pools provides an additional indication of the sand conditions a single plant may endure. The sand depth variance of $S$, sinicola was significantly greater than the variances for $S$. herporhizum and $S$. johnstonii $(p<.05$, Levene's test, Dixon and Brown, 1979), reflecting the more variable sand level in the habitat of $S$. sinicola in the deeper parts of pools.

\section{DISCUSSION}

The distributions of Sargassum johnstonii, S, herporhizum, and $S$. sinicola show distinct differences in vertical zonation and habitat. Intertidal Sargassum plants at Station Beach occurred in 2 distinctly sepa- 
Fig. 8. Mean length of Sargassum species in Station Beach tide pools

Fig. 9. Mean sand depth of Sargassum species in Station Beach tide pools
ह
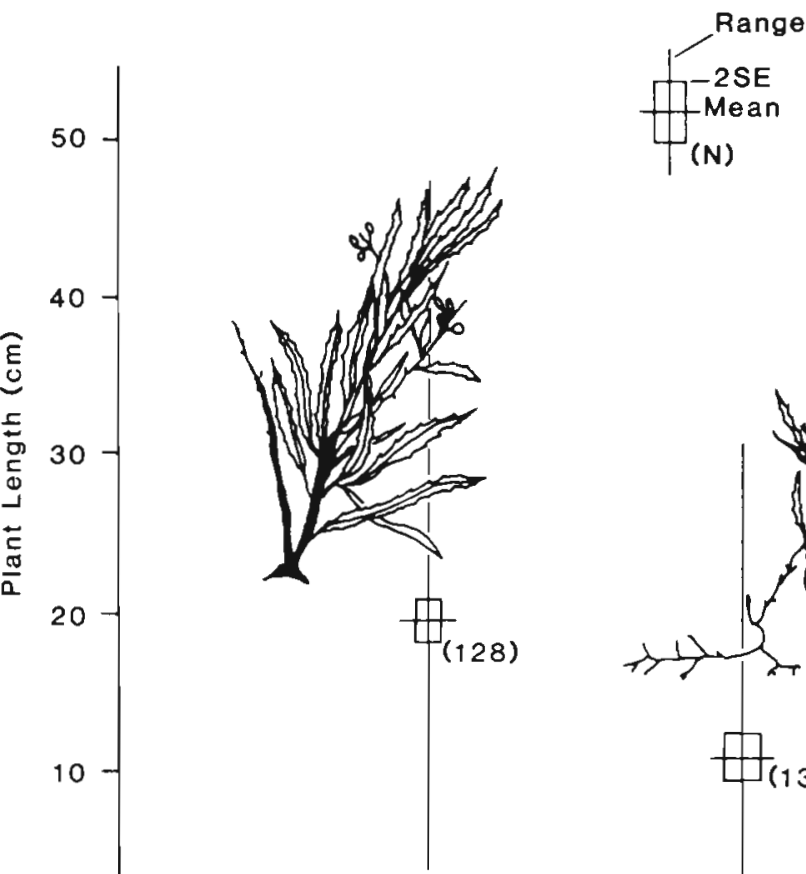

S. sinicola
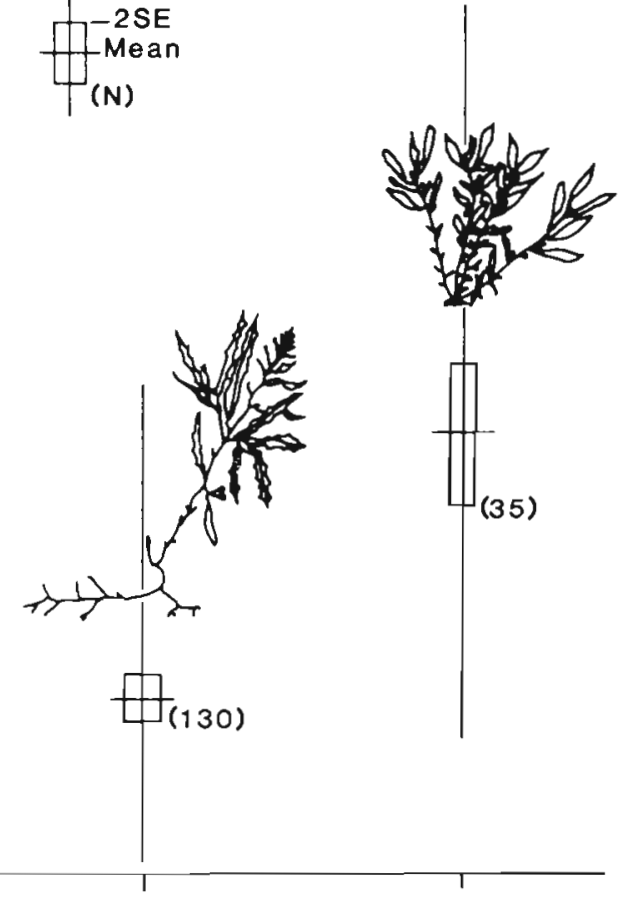

S. johnstonii

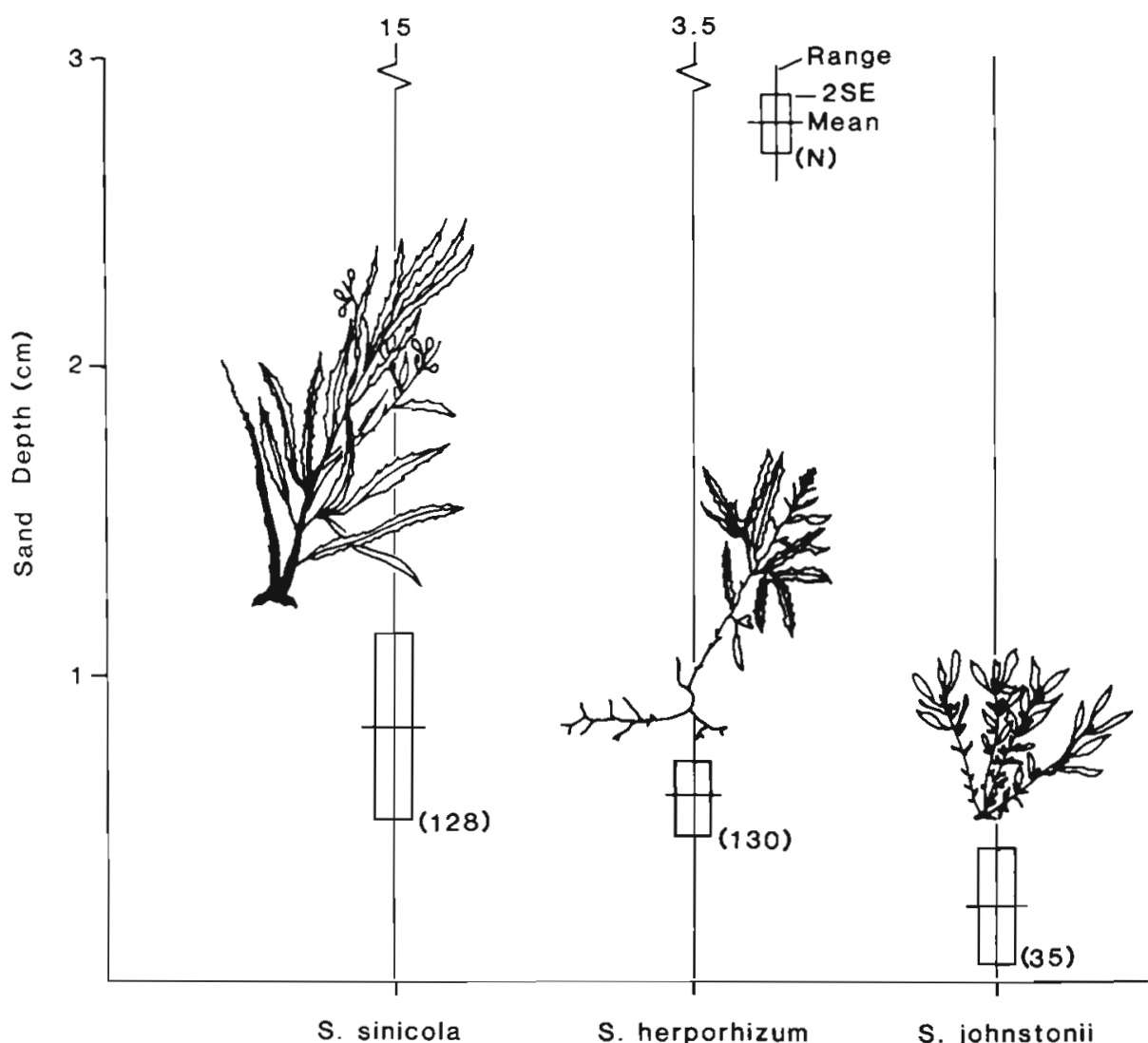


rate zones: in mid-intertidal pools above the reef fault (above zero-tide level) and in pools and on ernergent coquina below the fault (below zero-tide level) (Fig. 2). This distribution pattern is similar to that of an introduced species, $S$. muticum, in the Strait of Georgia, British Columbia, as reported by De Wreede (1978), who also found Sargassum plants in 2 separate areas, one in the upper and one in the lower intertidal zone. These results do not necessarily contradict the conclusions of Brusca (1980) and Mackie and Boyer (1977) on the discreteness of intertidal invertebrate communities in the Gulf of California. They described a lack of discreteness in the zonation of communities in this region, whereas this study reveals clear differences between a set of closely related species. The existence of a 3-species zonation pattern within the setting of a more diffuse pattern of community zonation indicates that the Sargassum species, though abundant as canopy organisms, do not exert a dominating, patterninducing effect on zonation.

In the lower zone at Station Beach Sargassum sinicola dominated pools, whereas $S$. johnstonii and $S$. herporhizum grew primarily on emergent coquina (Fig. 2). Although the latter 2 species shared the same emergent habitat type, they were vertically zoned, with S. johnstonii higher on the shore (Fig. 2). Within pools in the upper zone vertical zonation of the 3 species with respect to water depth was observed (Fig. 7). The zonation pattern in pools was similar to that found on emergent substrates in the lower zone: $S$. sinocola occurred in the deepest water, $S$. herporhizum in intermediate depths, and $S$. johnstonii in the shallowest. In summary, when 2 or 3 species occupy the same habitat type at low tide (pool or emergent coquina) they occur in different vertical zones, whereas when they occupy the same vertical zone they occur in different habitat types.

Physical factors usually set the upper limits to a species' intertidal distribution (Connell, 1972, 1974). The physical factors most likely affecting zonation of the 3 Sargassum species in pools and in the intertidal zone as a whole are exposure to air and sand stress in the form of scour or burial. Norton (1977) showed that desiccation in summer and frosting in winter affected the upper intertidal limit of $S$. muticum in the San Juan Islands. Drying experiments on Puerto Peñasco species (McCourt, 1983) showed that $S$. johnstonii, the uppermost species in all zonation patterns, lost water more slowly than the other 2 species. Different rates of desiccation at low tide probably set the different upper limits of the three Sargassum species on emergent coquina habitats.

At Pelican Point and Las Conchas the upper limits of Sargassum johnstonii in the intertidal zone coincide with changes in substrate. The deep sand at Las Con- chas is obviously unsuitable for juvenile settlement. Sargassum plants do grow on granite in some tide pools at Pelican Point, however, and the reason for their absence from this substrate is unclear. Coquina is porous and retains some water at low tide, making it a cooler surface to grow on. Higher temperatures on nonporous granite surfaces in the mid-intertidal zone may preclude settlement and survival of even the desiccation-resistant $S$. johnstonii.

Exposure to air may also affect the small-scale zonation of plants in tide pools in the mid-intertidal zone. Although these habitats are by and large continously submerged, plants at the edges of pools will be subject to greater probability of desiccation due to minor changes in pool water depth (gradual draining during low tide) or random positioning of plants. Sargassum johnstonii, the species with the slowest rate of water loss, is found at pool edges in the shallowest water. Plants of this species are commonly found at low tide with holdfasts anchored in only a few centimeters of water, whereas most branches lie on adjacent emergent reef. Certainly the greater desiccation resistance of this species is important in allowing it to occur here.

Sargassum johnstonii in tide pools show no correlation of plant height with water depth. Its greater resistance to desiccation may free it from the need to be completely submerged in the mid-intertidal zone and thereby also allow it to reach a larger size in this habitat and increase the amount of reproductive structures produced.

The positive correlation between plant length and pool depth reported here for Sargassum sinicola and $S$. herporhizum was also reported by De Wreede (1978) for $S$. muticum in pools in the Strait of Georgia. This correlation is interesting because plants spend most of their time submerged by several meters of water at high tide. A plant's length may depend more on the character of its habitat when the tide is out than when the tide is in. De Wreede (1978) found that intertidal $S$. muticum plants were more highly branched than lower intertidal forms. When under water the lateral Sargassum branches with their air bladders float upward, and they may branch rather than keep elongating when they reach the surface of pools. If distal segments are removed or damaged by desiccation at the surface of a pool, increased branching or development of blades may be induced (Fagerberg and Dawes, 1977).

The absence of Sargassum herporhizum from the very sandy Las Conchas site suggests that sand burial or scour may have an adverse effect on this species. The absence of this species with a rhizoidal holdfast from a sandy habitat is anomalous compared to some kelp species with rhizoidal holdfasts that occur in sites subject to severe sand scour. Markham (1972, 1973a, b) found that Laminaria sinclairii (Harvey) Farlow, 
Anderson \& Eaton in sand-scoured habitats reproduces primarily through the spread of its rhizoidal holdfast. Markham (1973a) reasoned that microscopic gametophytes were scoured off surfaces by sand, whereas adults could survive and spread vegetatively once established. By analogy, $S$. herporhizum adults should also thrive in sandy areas where juvenile recruitment is low but they do not. McCourt et al. (1984) reported evidence of unpredictable long-term burial of portions of the coquina reef at Las Conchas that killed nearly all attached plants and animals. Nevertheless, it is not clear why $S$. herporhizum should be more susceptible to damage from sand than the other two Sargassum species.

Several researchers (Ebert and Dexter, 1975; Thomson and Lehner, 1976; Littler and Littler, 1981) have suggested that communities in the northern Gulf of California are more influenced by physical factors (temperature fluctuations, desiccation) than by biological factors (competition, predation). Littler and Littler (1981) claimed that the seasonally disturbed environment of the northern gulf has selected for structurally simple, opportunistic algal species with high individual net productivity. They cited the species composition and productivity of intertidal communities at Pelican Point in support of this hypothesis. But their study site, though near that of the present work, sampled algae from higher intertidal areas on granite and failed to include the extensive stands of Sargassum on coquina in the lower intertidal area. The 3 Sargassum species, occurring in the more constant environment of the lower intertidal zone, are better described by Littler and Littler's generalizations regarding intertidal algal communities at comparable latitudes outside the Gulf of California: long-lived, large, complex thalli, with low individual net productivity. Littler and Littler stated that these features enable species to better cope with biological interactions (competition, predation).

Little is known of the effects of herbivores on Sargassum distributions, although adult plants are generally not preferred by herbivorous fish (Montgomery and Gerking, 1980; Montgomery et al., 1980).

Differences in spatial distribution such as those reported here for the Sargassum species are sometimes interpreted as evidence of present or past competition between species (Schoener, 1982). That competition between the species may be occurring in some places now is suggested by the habitat shift from mostly tide pools to mostly emergent coquina by $S$. sinicola at sites where pools are less abundant and $S$. herporhizum is rare or absent (Las Conchas, Pelican Point) (Fig. 6). This shows that $S$. sinicola can survive in large numbers on emergent substrate at this intertidal level $(-1.8 \mathrm{~m})$ in the intertidal zone. That it occurs mostly in tide pools at Station Beach suggests that it may be excluded from the emergent habitat by large stands of $S$. herporhizum. Nevertheless, clearing of singlespecies stands of Sargassum during the spring period of sexual reproduction and dispersal resulted in the regrowth of the original resident, regardless of species cleared (McCourt, 1983). In addition, the differences in distribution, though distinct, do not often result in contiguous stands of different species of Sargassum, which would be the precinct of the most intense competition. This indicates that competition, if it does occur, is probably infrequent and sporadic.

Acknowledgements. I thank Drs. D. A. Thomson, R. W. Hoshaw, J. R. Hendrickson, A. Kodric-Brown, and J. H. Brown of The University of Arizona for advice during the course of the research. I am grateful to my colleagues, Dr. N. P. Yensen and M. L. Dungan, who reviewed drafts of the manuscript. Partial financial support was provided by a National Science Foundation pre-doctoral fellowship and by the Graduate College Development Fund of The University of Arizona. I thank the University of Sonora and the Center for the Study of Deserts and Oceans for allowing me access to their facilities in Puerto Peñasco

\section{LITERATURE CITED}

Brusca, R. C. (1980). Common intertidal invertebrates of the Gulf of California, 2nd edition. University on Arizona Press, Tucson

Connell, J. H. (1972). Community interactions on marine rocky intertidal shores. A. Rev. Ecol. Syst. 3: 169-192

Connell, J. H. (1974). Ecology: field experiments in marine ecology. In: Mariscal, R. N. (ed.) Experimental marine biology. Academic Press, New York, p. 21-54

Dawes, C. J. (1981). Marine botany. John Wiley and Sons, New York

Dawson, E. Y. (1944). The marine algae of the Gulf of California. Allan Hancock Pacif. Exped. 3: 189-452

Dawson, E. Y. (1966). Marine algae in the vicinity of Puerto Peñasco. Gulf of California Field Guide Series No. 1. University of Arizona, Tucson

De Wreede, R. E. (1973). The ecology of Sargassum in Hawaii, with reference to the species in Micronesia. Ph. D. dissertation, University of Hawail, Honolulu

De Wreede, R. E. (1976). The phenology of three species of Sargassum (Sargassaceae, Phaeophyta) in Hawaii. Phycologia 15: 175-183

De Wreede, R. E. (1978). Phenology of Sargassum muticum (Phaeophyta) in the Strait of Georgia, British Columbia. Syesis 11: 1-9

Dixon, W. J., Brown, M. B. (ed.) (1979). BMDP-79. Biomedical computer programs, P-series. University of California Press, Berkeley

Ebert, T. A., Dexter, D. M. (1975). A natural history study of Encope grandis and Mellita grantii, two sand dollars in the northern Gulf of California, Mexico. Mar. Biol. 32: $397-407$

Fagerberg, W. F., Dawes, C. J. (1977). Studies on Sărgassum II. Quantitative ultrastructural changes in differentiated stipe cells during wound regeneration and growth. Protoplasma 92: 211-227

Fritsch, F. E. (1945). The structure and reproduction of the 
algae, Vol. II. Foreword, Phaeophyceae, Rhodophyceae, Myxophyceae. Cambridge University Press, Cambridge

Lewis, J. R. (1964). The ecology of rocky shores. The English Universities Press Ltd., London

Littler, M. M., Littler, D. S. (1981). Intertidal macrophyte communities from Pacific Baja Califomia and the upper Gulf of California: relatively constant vs. environmentally fluctuating systems. Mar. Ecol. Prog. Ser. 4: 145-158

Mackie, S. A., Boyer, E. H. (1977). Intertidal zonation of macroscopic invertebrates on the coquina reef at Playa de Estación, Puerto Peñasco, Sonora, Mexico. Bios. 48: 120-128

Markham, J. W. (1972). Distribution and taxonomy of Laminaria sinclairii and L. longipes (Phaeophyceae, Laminariales\}. Phycologia 11: 147-157

Markham, J. W. (1973a). Observations on the ecology of Laminaria sinclairii on three northern Oregon beaches. J. Phycol. 9: 336-341

Markham, J. W. (1973b). Studies on the haptera of Laminaria sinclairii (Harvey) Farlow, Anderson et Eaton. Syesis 1: 125-131

McCourt, R. M. (1983). Zonation and phenology of three species of Sargassum in the intertidal zone of the northern Gulf of California. Ph. D. dissertation, University of Arizona, Tucson

McCourt, R. M. (1984). Seasonal patterns of abundance, distributions, and phenology in relation to growth strategies of three Sargassum species. J. exp. mar. Biol. Ecol. 74: 141-156

McCourt, R. M., Michaels, A. F., Hoshaw, R. W. (1984). Distribution and seasonality of symbiotic Prochloron and its didemnid host in the northern Gulf of California. Phycologia 23: 95-101

Montgomery, W. L., Gerking, S. D. (1980). Marine macroalgae as foods for fishes: an evaluation of potential food quality. Env. Biol. Fish. 5: 143-153

Montgomery, W. L., Gerrodette, T., Marshall, L. D. (1980) Effects of grazing by the yellowtail surgeonfish, Prionurus punctatus, on algal communities in the Gulf of California, Mexico. Bull. mar. Sci. 30: 901-908

Norris, J. N. (1975). Marine algae of the northern Gulf of California. Ph. D. dissertation, University of California, Santa Barbara

Norris, J. N., Yensen, N. P. (in press). Sargassum (Fucales: Sargassaceae) in the northern Gulf of California. Smithson. Contr. mar. Sci.

Norton, T. A. (1977). Ecological experiments with Sargassum muticum, J. mar. biol. Ass. U. K. 57: 33-43

Prince, J. S., O' Neal, S. W. (1979). The ecology of Sargassum pteropleuron Grunow (Phaeophyceae, Fucales) in the waters off South Florida. I. Growth, reproduction and population structure. Phycologia 18: 109-114

Ricketts, E. F., Calvin, J., Hedgpeth, J. W. (1968). Between Pacific tides. 4th ed. Stanford University Press, Stanford, California

Schoener, T. W. (1982). The controversy over interspecific competition. Am. Scient. 70: 586-595

Stephenson, T. A., Stephenson, A. (1972). Life between tidemarks on rocky shores. W. H. Freeman and Company, San Francisco

Stewart, J. G. (1982). Anchor species and epiphytes in intertidal algal turf. Pacif. Sci. 36: 45-59

Thomson, D. A. (1981). Tide calendar for the northern Gulf of California. University of Arizona Printin-Reproductions, Tucson

Thomson, D. A., Lehner, C. E. (1976). Resilience of a rocky intertidal fish community in a physically unstable environment. J. exp. mar. Biol. Ecol. 22: 1-29

Tsuda, R. T. (1972). Morphological, zonational, and seasonal studies of two species of Sargassum on the reefs of Guam. In: Proceedings Seventh International Seaweed Symposium, Sapporo, Japan, August 1971. John Wiley and Sons, Inc. New York, p. 40-44

Wynne, M. J., Norris, J. W. (1976). The genus Colpomenia Derbes et Solier (Phaeophyta) in the Gulf of California. Smithson. Contr. Bot. 35: 1-18 